\begin{tabular}{l|c|c|}
\hline \hline & International Journal of Current Research in \\
\hline & Biosciences and Plant Biology \\
\hline $\begin{array}{c}\text { EXCELLENT } \\
\text { PUBLISHERS }\end{array}$ & Volume 6 • Number $\mathbf{5}$ (May-2019) • ISSN: 2349-8080 (Online) \\
\hline
\end{tabular}

\title{
Agricultural biodiversity: A special reference with North East India
}

\author{
Prabir Datta ${ }^{*}$, Utpalendu Debnath ${ }^{1}$, Smita Majumder², \\ C.K. Panda 3 and Sanjib Shil 4
}

${ }^{1}$ District Manager, North \& West Tripura District, Centre for Sustainable Agriculture, Hyderabad, India ${ }^{2}$ Block Technology Manager, Agril. Technology Management Agency, Dept. of Agriculture, Govt. of Tripura 3Assistant Professor, Bihar Agricultural University, Department of Extension Education, Sabour, India 4District Project Manager, North Tripura District, North East Rural Livelihood Project, Govt. of India

*Corresponding author; e-mail: agriprabir2009@gmail.com

\begin{tabular}{|c|c|}
\hline Article Info & \multirow{4}{*}{$\begin{array}{l}\text { Northeast India is known for its diverse nature of soil, climate, and topography. This } \\
\text { region is rich in diversity of many fruits, vegetables, flowers particularly orchids, spices, } \\
\text { bamboo and medicinal \& aromatic plants. Among the commercial fruits of the country, } \\
\text { maximum diversity in citrus, banana and jack fruit are found in Northeast India. A } \\
\text { large number of diversity in other tropical and subtropical fruits belonging to the } \\
\text { genera Garcinia, Artocarpus, Phyllanthus, Annona, Averrhoa, Persia, Aegle, } \\
\text { Passiflora, Tamarindus, etc. are reported from the region. Northeast India is also rich } \\
\text { in different genotypes of cucurbits, solanaceous vegetables, ginger, turmeric, bamboo, } \\
\text { leafy vegetables, etc. Among the different ornamental agricultural crops, the region has } \\
\text { the maximum diversity in orchids, fern and other flowering shrubs. Indigenous and } \\
\text { minor horticultural crops available in the region are however not being exploited } \\
\text { properly. These crops have the potentiality to alleviate the poverty, food and nutritional } \\
\text { insecurity through processing and value addition. Most of these crops are rich in } \\
\text { vitamins, minerals and such other bioactive molecules suitable for medicine, aromatic } \\
\text { and food processing industries. Protocols for preparation of instant ginger candy; } \\
\text { minimally processed ready-to-cook jack fruit; jam-jelly, fermented and non fermented } \\
\text { beverages from different indigenous fruits and tutti-frutti from chow-chow have already } \\
\text { been standardized. These value added products if produced commercially will go a long } \\
\text { way in increasing the area under these crops and thereby enhancing farm income and } \\
\text { nutritional security of the farmers. The aim is to preserve and promote agro- } \\
\text { biodiversity in the region by conserving seeds of indigenous varieties of food crops. The } \\
\text { concept of community seed banks at the grassroots level with farming communities } \\
\text { among small and marginal farmers for conserving, borrowing, lending and multiplying } \\
\text { their seeds. Seed banks can also facilitate farmers' access to markets and give the } \\
\text { farmers' more choice over what they grow. Seed banks enable rural tribal villages to } \\
\text { become less dependent on engineered high-yield varieties and on expensive inputs such } \\
\text { as fertilizers and pesticides. }\end{array}$} \\
\hline $\begin{array}{l}\text { Date of Acceptance: } \\
\text { o9 April } 2019\end{array}$ & \\
\hline Keywords & \\
\hline $\begin{array}{l}\text { Agriculture } \\
\text { Biodiversity } \\
\text { Community seed banks } \\
\text { Horticultural crops } \\
\text { North East India }\end{array}$ & \\
\hline
\end{tabular}




\section{Introduction}

Agricultural biodiversity is a sub-set of general biodiversity. It includes all forms of life directly relevant to agriculture: rare seed varieties and animal breeds (farm biodiversity), but also many other organisms such as soil fauna, weeds, pests, predators and all of the native plants and animals (wild biodiversity) existing on flowing through the farm. However, most attention in this field is given to crop varieties and to crop wild relatives. Cultivated varieties can be broadly classified into "modern varieties" and "farmer's or traditional varieties".

Modern varieties are the outcome of formal breeding and are often characterized as 'high yielding'. For example, the short straw wheat and rice varieties of the Green Revolution. In contrast, farmer's varieties (also known as landraces) are the product of (breeding and) selection carried out by farmers. Together, these varieties represent high levels of genetic diversity and are therefore the focus of most crop genetic resources conservation efforts.

Agricultural biodiversity will also be absolutely essential to cope with the predicted impacts of climate change, not simply as a source of traits but as the underpinnings of more resilient farm ecosystems. Agricultural biodiversity is the basis of our agricultural and uncultivated food chain, developed and safeguarded by farmers, livestock breeders, forest workers, fishermen and indigenous peoples throughout the world. The use of agricultural biodiversity (as opposed to nondiverse production methods) can contribute to food security and livelihood security.

Although the term agricultural biodiversity is relatively new- it has come into wide use in recent years as evidenced by bibliographic references- the concept itself is quite old. It is the result of the careful selection and inventive developments of farmers, herders and fishers over millennia. Agricultural biodiversity is a vital sub-set of biodiversity. It is a use of life, i.e. ancillary biotechnologies, by Mankind whose food and livelihood security depend on the sustained management of those diverse biological resources that are important for food and agriculture. As for everything, agricultural biodiversity can be used, not used, misused and even abused.

Agricultural biodiversity includes:

- Domesticated crop and 'wild' plants (called: crop wild relatives), including woody perennials (see: forest genetic resources) and aquatic plants (used for food and other natural resources based products), domestic and wild animals (used for food, fibre, milk, hides, furs, power, organic fertilizer), fish and other aquatic animals, within field, forest, rangeland and aquatic ecosystems.

- Domesticated livestock species and their wild relatives

- Non-harvested species within production agro ecosystems that support food provision, including soil micro-biota, pollinators and so on.

- Non-harvested species in the wider environment that support food production agro ecosystems (agricultural, pastoral, forest and aquatic ecosystems).

However, agricultural biodiversity sometimes called Agro biodiversity, "encompasses the variety and variability of animals, plants and micro-organisms which are necessary to sustain key functions of the agro ecosystem, its structure and processes for, and in support of, food production and food security”. It further "comprises genetic, population, species, community, ecosystem, and landscape components and human interactions with all these.

Aquatic diversity is also an important component of agricultural biodiversity. The conservation and sustainable use of local aquatic ecosystems, ponds, rivers, coastal commons by artisanal fisher folk and smallholder farmers is important to the survival of both humans and the environment. Since aquatic organisms, including fish, provide much of our food supply as well as underpinning the income of coastal peoples, it is critical that fisher folk and smallholder farmers have genetic reserves and sustainable ecosystems to draw upon as aquaculture and marine fisheries management continue to evolve. 


\section{Genetic erosion in agricultural and livestock biodiversity}

Genetic erosion in agricultural and livestock biodiversity is the loss of genetic diversity, including the loss of individual genes, and the loss of particular combinations of genes (or gene complexes) such as those manifested in locally adapted landraces or breeds. The term genetic erosion is sometimes used in a narrow sense, such as for the loss of alleles or genes, as well as more broadly, referring to the loss of varieties or even species. The major driving forces behind genetic erosion in crops are: variety replacement, land clearing, overexploitation of species, population pressure, environmental degradation, overgrazing, policy and changing agricultural systems.

The main factor, however, is the replacement of local varieties by high yielding or exotic varieties or species. A large number of varieties can also often be dramatically reduced when commercial varieties (including GMOs) are introduced into traditional farming systems. Many researchers believe that the main problem related to agroecosystem management is the general tendency towards genetic and ecological uniformity imposed by the development of modern agriculture. Pressures for that ecological uniformity on farmers and breeders are caused by the food industry demand for more and more raw materials consistency.

In the case of Animal Genetic Resources for Food and Agriculture, major causes of genetic erosion are reported to include indiscriminate crossbreeding, increased use of exotic breeds, weak policies and institutions in animal genetic resources management, neglect of certain breeds because of a lack of profitability or competitiveness, the intensification of production systems, the effects of diseases and disease management, loss of pastures or other elements of the production environment, and poor control of inbreeding.

\section{Genetic vulnerability}

In plant breeding, a population of plants is considered genetically vulnerable if there is little genetic diversity within the population, and this lack of diversity makes the population as a whole particularly vulnerable to disease, pests, or other factors. The problem of genetic vulnerability often arises with modern crop varieties, which are uniform by design.

An example of the consequences of genetic vulnerability occurred in 1970 when corn blight struck the US Corn Belt, destroying $15 \%$ of the harvest. A particular plant cell characteristic known as Texas male sterile cytoplasm conferred vulnerability to the blight- a subsequent study by the National Academy of Sciences found that 90\% of American maize plants carried this trait.

\section{Change in agricultural biodiversity in human diet}

Since 1961, human diet across the world have become more diverse in the consumption of major commodity staple crops, with a corollary decline in consumption of local or regionally important crops, and thus have become more homogeneous globally. The differences between the foods eaten in different countries were reduced by $68 \%$ between 1961 and 2009. The modern "global standard" diet contains an increasingly large percentage of a relatively small number of major staple commodity crops, which have increased substantially in the share of the total food energy (calories), protein, fat and food weight that they provide to the world's human population, including wheat, rice, sugar, maize, soybean (by $+284 \%$ ), palm oil (by $+173 \%$ ), and sunflower (by +246\%). Whereas nations used to consume greater proportions of locally or regionally important crops, wheat has become a staple in over $97 \%$ of countries, with the other global staples showing similar dominance worldwide. Other crops have declined sharply over the same period, including rye, yam, sweet potato (by $-45 \%$ ), cassava (by 38\%), coconut, sorghum ($52 \%$ ) and millets (by $-45 \%$ ).

\section{Human dependency}

Agricultural biodiversity is not only the result of human activity but human life is dependent on it not just for the immediate provision of food and other natural resources based goods, but for the maintenance of areas of land and waters that will sustain production and maintain agro ecosystems and the wider biological and environmental services (biosphere). 


\section{Agricultural biodiversity provides}

- Sustainable production of food and other agricultural products emphasizing both strengthening sustainability in production systems at all levels of intensity and improving the conservation, sustainable use and enhancement of the diversity of all genetic resources for food and agriculture, especially plant and animal genetic resources, in all types of production systems.

- Biological or life support to production emphasizing conservation, sustainable use and enhancement of the biological resources that support sustainable production systems, particularly soil biota, pollinators and predators.

- Ecological and social services provided by agro-ecosystems such as landscape and wildlife protection, soil protection and health (fertility, structure and function), water cycle and water quality, air quality, CO sequestration, etc.

- Research supporting these findings addresses multifunctional agriculture in Europe, home gardens from around the world, smallholder farms in the tropics among others.

\section{Comparisons of cropping systems}

The general trend noticed by the analysis of biodiversity present in different cropping systems (e.g., industrial agriculture and organic farming) was that the greater the diversity of crops(temporally and spatially) resulted in the greater overall biodiversity of the agro ecosystem, though this is not always the case. A meta-analysis of studies comparing biodiversity noted that, when compared to organic cropping systems, conventional systems had significantly lower species richness and abundance (30\% greater richness and 50\% greater abundance in organic systems, on average), though $16 \%$ of studies did find a greater level of species richness in conventional systems. Another study found that cropping systems that required heavy use of chemical amendments (e.g., the widespread broadcasting of pesticides and glyphosate, a practice ubiquitously found throughout the United States and Canada) had significantly greater levels of pollination deficits, whereas organic fields of the same crop (Canola) witnessed no pollination deficits. Other cropping systems like permaculture have undergone little study to determine relative levels of biodiversity compared to other cropping systems, but because they continue to reinforce the goals of increasing overall crop biodiversity, it can be extrapolated that an even greater level of biodiversity would be observed.

\section{Agro-ecosystem Vs. natural ecosystems}

Agricultural biodiversity has spatial, temporal and scale dimensions especially at agroecosystem levels. These agrosystems-ecosystems that are used for agriculture are determined by three sets of factors: the genetic resources (biodiversity), the physical environment and the human management practices. There are not many ecosystems in the world that are "natural" in the sense of having escaped human influence. Most ecosystems have been to some extent modified or cultivated by human activity for the production of food and income and for livelihood security. However, most agricultural areas can be returned to their natural landscape after subsequent generations.

"Over the past 50 years, we are seeing that diet around the world is changing and they are becoming more similar- what we call the Colombia-based International Centre for Tropical Agriculture, said.

"This diet is composed of big, major crops such as wheat, rice, potatoes and sugar." It also includes crops that were not important 50 years ago but have become very important now, partially oil crops like soybean, " he told BBC News. While wheat has long been a staple crop, it is now a key food in more than $97 \%$ of countries listed in UN data, the study showed and from relative obscurity, soybean had become "Significant" in the diet of almost three-quarters of nations. He added that while these food crops played a major role in tackling global hunger, the decline in crop diversity in the globalised diet limited the ability to supplement the energy-dense part of the diet with nutrient-rich foods. Amid the crops recording a decline in recent decades were millets, rye, yams, sweet potatoes and cassava. 


\section{THE NORTH EASTERN REGION OF INDIA}

The Northeast region of India comprising of the states of the states of Arunachal Pradesh, Assam, Meghalaya, Manipur, Tripura, Mizoram, Nagaland and Sikkim can be physiographically categorized into the Eastern Himalayas, Northeast hills (Patkai-Naga Hills and Lushai Hills) and the IndoMalayan, Indo-Chinese and Indian biogeographically realms, the NE region is unique in providing a profusion of habitats, which features diverse biota with a high level of endemism. The region is also the abode of approximately 225 tribes in India, out of 450 in the country, the culture and customs of which have an important role in understanding biodiversity conservation and management issues.

The north eastern region has been in focus for its high biodiversity and this region has been a priority for leading conservation agencies of the world. While WWF has identified the entire Eastern Himalayas as a priority Global 200 Ecoregion while conservation International has up scaled the Eastern Himalaya Hotspot which initially covered the states of Arunachal Pradesh, Sikkim, Darjeeling Hills, Bhutan and Southern China to the Indo Burma Hotspot (Myers, 2000) which now includes all the eight states of NorthEast India, along with the neighboring countries of Bhutan, Southern China and Myanmar. The richness of the region's avifauna largely reflects the diversity of habitats associated with a wide altitudinal range.

North East India supports some of the highest bird diversities in the orient with about 850 bird species. The Eastern Himalaya and the Assam plains have been identified as an Endemic Birds, (ICBP, 1992). The global distribution of 24 Restricted range species is limited to the region. The region's lowland and montane moist to wet tropical evergreen forests are considered to be the northernmost limit of true tropical rainforests in the world (Proctor et al., 1998).

The region has been identified by the Indian Council of Agricultural Research (ICAR) as a centre of rice germplasm while the National Bureau of Plant Genetic Resources (NBPGR), India, has highlighted the region as being rich in wild relatives of crop plants. It is the centre of origin of citrus fruits. Two primitive variety of maize, Sikkim Primitive 1 and 2 have also been reported from Sikkim (Dhawan, 1964). Although jhum cultivation, a traditional system of agriculture, is often cited as a reason for the loss of forest cover of the region this primary agricultural economic activity practiced by local tribes reflects the usage of 35 varieties of crops. The region is rich in medicinal plants and many other rare and endangered taxa. Its high endemism in higher plants, vertebrates and avian diversity has qualified it to be a biodiversity 'hotspot' and this aspect has been elaborated in details in the subsequent sections.

IUCN in 1995 identified Namdapha in Arunachal Pradesh as a centre of plant diversity. The following figures highlight the biodiversity significance of the region (Hegde, 2000, FSI, 2003):

1. 51 Forest types are found in the region broadly classified into six major forest types viz., tropical moist deciduous evergreen forests, tropical semi evergreen forests, tropical wet evergreen forests, subtropical forests, temperate forests and alpine forests.

2. Out of the 9 important vegetation types of India, 6 are found in the North Eastern region.

3. These forests harbour 80,000 out of 15,000 species of flowering plants, these include

- 40 out of 54 species of gymnosperms.

- 500 out of 1012 species of Pteridophytes

- 825 out of 1145 species of orchids.

- 80 out of 90 species of rhododendrons

- 60 out of 110 species of bamboo

- 25 out of 56 species of canes

In terms of floral species richness the highest diversity is reported from the states of Arunachal Pradesh and Sikkim amongst the North Eastern States as shown in the following table (Table 1): 
Table 1. Floral species richness reported from the North Eastern States.

\begin{tabular}{ll}
\hline State & $\begin{array}{l}\text { Species richness } \\
\text { (flowering plants) }\end{array}$ \\
\hline Arunachal Pradesh & 5000 \\
Sikkim & \pm 4500 \\
Meghalaya & \pm 3500 \\
Assam & \pm 3010 \\
Manipur & \pm 2500 \\
Nagaland & \pm 2250 \\
Mizoram & \pm 2200 \\
Tripura & \pm 1600 \\
\hline
\end{tabular}

4. These species belong to about 200 plant families out of 315 recorded from North East India. Some of the families such as Nepanthaceae, Illiciaceae and Clethraceae are unique in the world. These families are reported from the South East Asian countries and are represented by a limited number of species like Clethra sp. and
Nepenthus khasiana in North east India (A.R.K. Sastry pers. comm.).

5. According to the Indian Red data book published by the Botanical Survey of India, $10 \%$ of the total flowering plants in the country are endangered. Of the 1500 endangered floral species, 800 are reported from North East India.

6. High biological diversity is often related to the forest cover of a region. Most of the North Eastern States have more than 60\% of their geographical area under forest cover, a minimum suggested coverage for the hill states in the country. The percentage of forest cover recorded during the assessments in the years 2001 and 2003 by the Forest Survey of India is given in Table 2.

Table 2. Scenario of forest cover in North East India (Areas in Sq.km.).

\begin{tabular}{lllll}
\hline N.E. States & $\begin{array}{l}\text { Geographical area } \\
\text { of the state }\end{array}$ & $\begin{array}{l}\text { Forest cover in } \\
\mathbf{2 0 0 3} \text { (Total) }\end{array}$ & $\begin{array}{l}\text { Percentage forest } \\
\text { cover in the state }\end{array}$ & $\begin{array}{l}\text { Forest cover in } \\
\text { 2oo1 }\end{array}$ \\
\hline Arunachal Pradesh & 83,743 & 68,019 & 81.22 & 68,045 \\
Assam & 78,438 & 27,826 & 24.04 & 27,714 \\
Manipur & 22,327 & 17,219 & 77.12 & 16,926 \\
Meghalaya & 22,429 & 16,839 & 75.08 & 15,584 \\
Mizoram & 21,081 & 18,430 & 87.42 & 17,494 \\
Nagaland & 16,579 & 13,609 & 82.09 & 13,345 \\
Sikkim & 7,096 & 3,262 & 45.97 & 3,193 \\
Tripura & 10,486 & 8,093 & 77.18 & 7,065 \\
\hline
\end{tabular}

7. The faunal diversity is relatively better documented than its floral counter parts for the North Eastern region. However the discovery of newer species like the Tawang Macaque (Macaca sp) and range extensions of the Chinese goral (Nemorhaedatus caudatus) and leaf deer (Mentiacus putaoensis) highlights the dire need for more extensive research and systematic documentation of biodiversity of the North East.

Agriculture is our future, today. And biodiversity is the foundation of that future and seed biodiversity is the primary for livelihood, nutritional and food security, health and dignity of rural areas especially for hill people and traditional farmers.

\section{Conflict of interest statement}

Authors declare that they have no conflict of interest.

\section{References}

A.R.K. Sastry, pers. comm. Biodiversity, Botanic Gardens and Plant Conservation in India.

Bibby, C.J., Crosby, M.J., Heath, M.F., Johnson, T.H., Long, A.J., Stattersfield, A.J., Thirgood, S.J., 1992. Putting biodiversity on the map: global priorities for conservation. International Council for Bird Preservation, Cambridge, United Kingdom.

B.B.C report on North East forest (www.bbc.co.uk/news/uk-scotland-north-eastorkney-shetland-18802746). 
Dhawan, N.L., 1964. Primitive maize in Sikkim. Maize Genetics Co-op Newsletter. 38,69-70.

Hegde, S.N., 2000. Conservation of North East Flora. Arunachal Forest News. Vol 18 (1), p.2.

Forest Survey of India reports. 2003. Dehradun.

IUCN. 1995. Centres of Plant Diversity. Asia, Australia and the Pacific.Vol 2. International Union for Conservation of Nature, Publications Services Unit, Cambridge, UK.

Indian council of Agricultural Research, New
Delhi, NE forest report (2012).

Myers, N., Mittermeier, R.A., Mittermeier, C.G., Da Fonseca, G.A., Kent, J., 2000. Biodiversity hotspots for conservation priorities. Nature, 403(6772), p.853.

Proctor, J., Haridasan, K., 1998. How far north does lowland evergreen tropical rain forest go?. Global Ecol. Biogeogr. Lett. 7(2), 141-146.

WWF-India Report (Unpublished) Sacred High Altitude Lakes of Sikkim, 2005.

\section{How to cite this article:}

Datta, P., Debnath, U., Majumder, S., Panda, C.K., Shil, S., 2019. Agricultural biodiversity: A special reference with North East India. Int. J. Curr. Res. Biosci. Plant Biol. 6(5), 39-45.

doi: https://doi.org/10.20546/ijcrbp.2019.605.005 